\title{
Social Problems of Industrial Development of the Arctic Territories
}

\author{
Evgenia V. Potravnaya* \\ Interregional Centre for Environmental Audit and Consulting \\ Moscow, Russian Federation
}

Received 24.05.2021, received in revised form 15.06.2021, accepted 29.06.2021

\begin{abstract}
The article considers the mechanism of taking into account and evaluating the opinion of the population when implementing investment projects for industrial development of the territory in the Russian Arctic. To identify priority social problems, it is proposed to conduct sociological surveys of the population throughout the life cycle of projects. The information base of the study was the materials of ethnological expertise of projects for the exploration and production of alluvial diamonds in the Anabar and Oleneksky ulus (districts) of the Republic of Sakha (Yakutia), as well as sociological surveys of the population in the framework of assessing the consequences of the diesel fuel spill in Norilsk and the consequences of its impact in the Taimyr Dolgan-Nenets Municipal District of the Krasnoyarsk region.

Based on the conducted surveys of the population, the article identifies social problems associated with the industrial development of the territory and gives a comparative analysis of social problems at different stages of the implementation of mining projects. Besides, the article discusses the low level of income of the population, the outflow of young people, the reduction in the number of objects of traditional use, and the problems of preserving cultural traditions. It also draws conclusions about the relationship of social problems and proposes measures to reduce the consequences of identified social problems.
\end{abstract}

Keywords: Industrial development of the territory, project, social problems, the Arctic, indigenous peoples, ethnological expertise, economic sociology.

The article was prepared with the support of the grant of the Russian Foundation for Basic Research (RFBR), project No. 20-010-00252 «Economic and legal mechanisms of regulation and development of territories of traditional nature use in the context of industrial development of the Arctic».

Research area: economic sociology.

Citation: Potravnaya, E.V. (2021). Social problems of industrial development of the Arctic territories. J. Sib. Fed. Univ. Humanit. Soc. Sci., 14(7), 1008-1017. DOI: 10.17516/1997-1370-0780.

\footnotetext{
(C) Siberian Federal University. All rights reserved

* Corresponding author E-mail address: potr195@gmail.com ORCID: 0000-0003-3343-0253
} 


\title{
Социальные проблемы промышленного освоения арктических территорий
}

\author{
Е.В. Потравная \\ Межрегиональный центр экологического аудита и консалтинга \\ Российская Федерация, Москва
}

\begin{abstract}
Аннотация. В статье рассматривается механизм учета и оценки мнения населения при реализации инвестиционных проектов промышленного освоения территории в Российской Арктике. Для выявления приоритетных социальных проблем предлагается проведение социологических опросов населения по всему жизненному циклу проектов. Информационной базой исследования являлись материалы этнологической экспертизы проектов по разведке и добыче россыпных алмазов в Анабарском и Оленекском улусах (районах) Республики Саха (Якутия), а также социологические опросы населения в рамках оценки последствий разлива дизельного топлива в г. Норильске и последствия его влияния в Таймырском Долгано-Ненецком муниципальном районе Красноярского края. На основе проведенных опросов населения выделены социальные проблемы, связанные с промышленным освоением территории, дан сравнительный анализ социальных проблем на разных стадиях реализации добывающих проектов: низкий уровень доходов населения, отток молодежи, сокращение количества объектов традиционного пользования, проблемы сохранения культурных традиций. Сделаны выводы о взаимосвязи социальных проблем, предложены меры снижения последствий выявленных социальных проблем.
\end{abstract}

Ключевые слова: промышленное освоение территории, проект, социальные проблемы, Арктика, коренные малочисленные народы, этнологическая экспертиза, экономическая социология.

Статья подготовлена при поддержке гранта Российского фонда фундаментальных исследований (РФФИ), проект № 20-010-00252 «Экономико-правовые механизмы регулирования и развития территорий традиционного природопользования в контексте промышленного освоения Арктики».

Научная специальность: 22.00.03 - экономическая социология.

\section{Introduction}

Implementation of «Strategy for the Development of the Arctic Zone of the Russian Federation and Provision of National Security for the Period through 2035» (2020) deals with the implementation of a range of measures on socio-economic development of the territory including the implementation of investment projects for exploration and extraction of minerals, development of transport and social infrastructure. Such an approach is inextricably intertwined with the enhancement of life quality of the population, reduction in the population outflow from the Arctic region, employment creation, poverty reduction, and environmental improvement (Belonozhko et al., 2018).

Meanwhile, industrial development of the Arctic territories, implementation of projects on exploration and extraction of minerals may bring about adverse environmental impact, alongside with achieving positive socio-economic results (Burtseva, Potravny, Gassiy, 2019). It should be considered that most indigenous peoples of Russia live in the North where natural resources are being intensively developed. Such an activity is likely accompanied with the alienation of territories and a negative impact on habitual 
lifestyle of the local population (Gassiy, Potravny, 2019).

Industrial development of the Arctic affects the interests of the indigenous peoples of the North which is fraught with the issues of compensation for potential losses incurred by the indigenous peoples in the area of project implementation as well as with the issues of protection of their rights and provision of economic guarantees in terms of the impact made on their indigenous environment (Zander, Pyzheva, Pyzhev, 2014).

Inadequate attention to social and ethnological factors in the framework of industrial development of the Arctic may lead to the conflict of interests (Tysiachniouk et al., 2020). This implies the elaboration of measures on protection of rights and interests of the indigenous peoples in the context of implementation of investment projects in the Arctic zone of the Russian Federation (Tulaeva et al., 2019) as well as the development of a mechanism of providing sustainable socio-economic development in this territory and addressing the emerging social problems (Denisov et al., 2020).

Applying this approach is related to the development of mechanism of record keeping and evaluation for assessing the opinion of local population in the area of a planned and ongoing activity in terms of identification and addressing the emerging social problems.

\section{Theoretical framework}

In a broad sense, social problems are understood as specific situations, events or conditions that can make a direct or indirect negative impact on the society. Max Weber laid the foundations of the study of social problems that initially dealt with the issues of unequal distribution of wealth (Gerth, Turner, 2009; Kim, 2007). Later on, the nature and scope of social problems underwent a substantial transformation due to the changing economic, environmental and social circumstances as well as changes in the living standards, quality of life and sentiments of the people (Zarubina, Serova, 2018). For instance, implementation of a range of the Arctic projects may be accompanied with various losses, damages and lost benefits of the indigenous peoples of the North caused by withdrawal of the territories of traditional nature management for industrial purposes, reduction of their resource productive capacity, and transformation of ethnosocial living environment of the local population (Burtseva, Bysyina, 2019). In this context, the study and analysis of social problems in terms of industrial development of the Arctic territories is closely linked to the study of economic behaviour of the indigenous peoples (Potravnaya, Kim, 2020), consideration of gender sensitivity in terms of communication between mining companies and the local population (Potravnaya, 2020).

Moreover, new social problems that make an impact on the life of the indigenous peoples and the development of traditional industries can include effects of the COVID-19 pandemic (Sleptsov, Potravnaya, 2020). For instance, the COVID-19 pandemic exacerbates connection between responsible behaviour of population, such as self-isolation and social distancing, and economic behaviour of people such as keeping a job and earning income as well as their adaptation to harsh conditions of the pandemic situation.

In addition, climate change may be included in the list of new social problems in the Arctic context (Berman, Schmidt, 2019).

In this context, analysis and evaluation of positive and potential negative changes that are occurring or may occur in the future in the life of people living in the Arctic area in the framework of industrial development of the territory as well as the assessment of trends to such changes take on particular importance.

\section{Statement of the problem}

A specific problem considered in the article is the development of mechanism of social monitoring of public opinion in the context of implementation of projects on industrial development of the Arctic. Such a mechanism suggests the existence of a system of collection, analysis and inventory of data aimed at addressing the emerging problems and the development of methodological framework and analytics in regards to prospective lines of the development of the Artic territory. 
At present, in certain regions and subjects of the Russian Federation such as the Republic of Sakha (Yakutia), specific legal framework regulates the issues of carrying out ethnological evaluation of projects. This evaluation will allow assessing the impact of changes of primordial living environment of the indigenous peoples and sociocultural situation made on the ethnos development (Sleptsov, Petrova, 2019). A widespread use of sociological methods of research is suggested for applying this approach.

Globalization processes are inextricably intertwined with the industrial development of the Arctic region. The industrial development involves close interaction between the indigenous peoples and mining companies. Hence it follows that the nature of this communication is bilateral. This is how local people that had been primordially living in the region that is rich in natural resources accept industrial development of their territory. The companies arranging their work in the areas where ethnic groups with their traditions and culture had been historically living should build up effective relations with these population groups in order to resolve the problems of individuals and contribute to socio-economic development of the entire territory. Such a type of communication became a frequent practice in terms of corporate social responsibility. Most major companies implementing their projects in the North such as Nornickel have special units on relations with the indigenous peoples.

However, the processes that are underway in the Arctic districts show that the corporate social policy may be insufficient, or, in contrast can bring about positive outcomes for social life of the society. For instance, it can be observed that COVID-19 pandemic of 2020 contributed to global identification of social problems which require new solutions. Moreover, in this regard one should mention the social problems that emerged due to the environmental harm caused by the ecological disaster in Norilsk in the context of traditional industrial development of the region.

Local people perceive the outflow of young people from the region as a social-economic problem which may hinder the development of the Arctic districts.

Therefore, carrying out sociological research in the framework of justification and implementation of investment projects in the Arctic should contribute to stabilization of social tension in the context of implementation of investment projects aimed at the development of the Artic area. The goal of such research is addressing specific problems in the framework of individual projects as well as accumulating and generalizing experiences of projects for developing comprehensive measures aimed at the development of the north areas.

\section{Methods}

The methodological framework of research is a concept of wealth distribution by stakeholders (business, authorities and local population) in the context of industrial development of the Arctic (Petrov, Tysiachniouk, 2019). One of research methods is ecological assessment of industrial development in the Arctic in terms of which the high-priority socio-economic, environmental and ethnological issues of public concern were identified in the framework of sociological surveys.

Thus, the research is based on results of sociological surveys carried out by the author with the involvement of population of the Arctic districts where projects on industrial development of the region are being implemented. The objective of research was to form a picture of social-psychological characteristics and motivation attitudes of the indigenous peoples of the Arctic in the area of planned activity, and identify trends of interaction between stakeholders based on the study of economic behaviour in the area of implementation of investment projects.

The surveys were carried out in the framework of the project ethnological evaluation in the Arctic region of the Russian Federation, particularly in the Republic of Sakha (Yakutia) and Taymyr Dolgano-Nenets Municipal District, the Krasnoyarsk Krai (Region). A cluster survey by a complete census was applied for the study where the clusters are settlements in the area of industrial development projects of the Arctic. All respondents involved in the 
sample were voting citizens aged 18 and older who were interviewed at special meetings with the representatives of a scientific expedition. A face-to-face questionnaire survey where respondents checked the applicable answers was applied as a method of research. In the course of questioning, representatives of the scientific expedition helped respondents who had difficulty understanding questions due to language problems.

As a model information base, they considered projects on assessing the impact made on ethnological environment for the exploration of alluvial diamonds and gold in the placers on the Anabar River, Olenyoksky District, the Ochuos stream, and the Lyaseger-Yuryakh stream, Anabarsky (Dolgano-Evenkiysky) national ulus (district) of the Republic of Sakha (2020), as well as the project on assessing the impact made on ethnological environment in terms of mitigation of consequences of Norilsk diesel oil spill that took place near Norilsk on 29 May, 2020.

\section{Discussion}

In the current context of industrial development of the Arctic, record keeping and evaluation of ethnosocial aspects of regional development takes on great importance. Ethnosocial aspects are understood as ethnic and social factors influencing behaviours of local population of the North in the context of implementing industrial projects in their region. Consideration and registration of such ethnological requirements should be carried out throughout the entire project life cycle.

Figure 1 shows the stages and procedures of applying sociological research on record keeping in terms of interests and preferences of the indigenous peoples of the North at various stages of the project life cycle. Consideration and record keeping of ethnological aspects in the framework of justification of investment projects on industrial development of the Arctic should cover the three key stages:

1) Carrying out sociological surveys involving population living in the investment project area at the stage of justification and ethnological evaluation of a planned activity.
2) Carrying out ethnological (ethnosocial) monitoring of the project at the implementation stage.

3) Carrying out ethnological audit at the finalizing stage of the project.

For instance, in the context of implementation of the project on exploration of alluvial diamonds on the Bolshaya River in Olenyoksky District (Yakutia), a part of the territory used for fishing, hunting, and wild crops conservation by local people may be removed from economic turnover. Such factors must be considered and discussed with local residents at the justification stage of the project (stages of public hearings and ethnological evaluation of the project). On the other hand, there are examples of implementation of investment projects which may cause environmental effect along with the social-economic impact and contribute to the development of ethnos and culture of the local population.

Carrying out ethnosocial research at this stage will allow for identification of expectations and preferences of the indigenous peoples of the North in the context of mining in the districts of traditional nature management including the issues of mining company's assistance in traditional nature management, raw material processing, and introducing state-ofthe-art technologies in food processing (meat and fish) (Fig. 1).

Objectives of sociological surveys are as follows:

1. Identification of local people's attitudes towards social-economic issues and environmental problems as well as to the issues related to traditional culture preservation; development of recommendations on improvement of the quality of life in the district.

2. Identification of most promising areas in the district development.

3. Identification of local people's attitudes towards economic activity of the companies involved in the area of mineral exploration and mining.

4. Identification of possible compensation formats in the context of economic activity in the district's territory.

5. Analysis of needs and attitudes of local residents that must be considered by business 


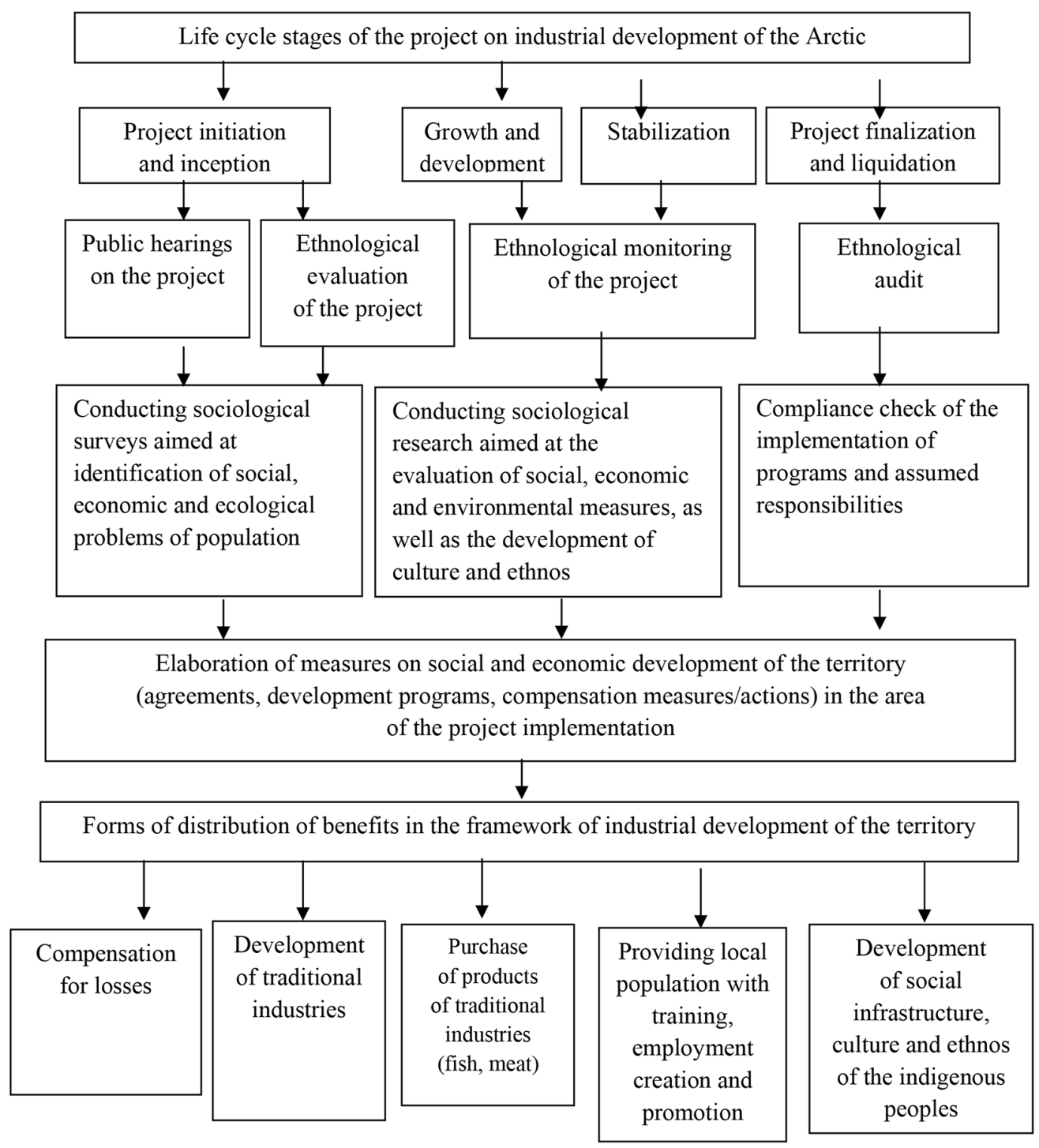

Fig. 1. Registration of ethnosocial aspects of development of life activity of the indigenous peoples of the North at various stages of life cycle of the projects on industrial development of the Arctic

companies in the framework of their economic activity.

On the other hand, carrying out sociological surveys in the framework of ethnological evaluation of consequences of accidental oil spill in Norilsk in 2020 allow for identifying changes that took place among the population after the accident and for determining high demand social issues including justification of compensatory measures of support of the in- digenous peoples and their traditional industries (Potravny, 2020; Samsonova et al., 2021).

After the project completion, it is recommended to carry out ethnological audit (stage of project finalization and liquidation) which will provide for evaluation of degree of conformity of declared project objectives and their implementation, and showing the extent to which the earlier declared project objectives and their implementation were considered in the project in 
terms of funding allocated by corporate subsoil user for social-economic, cultural and ethnos development in the district.

\section{Conclusion / Results}

Sociological surveys carried out in Olenyoksky District, Yakutia, in the framework of ethnological evaluation of the project on alluvial diamonds exploration and mining resulted in identification of key social-economic issues of the local people's major concern (Table 1).

The surveys were carried out in the rural localities of Olenyok and Kharyyalakh in August and September 2020 with the involvement of 130 respondents.

Increase in food prices is a problem of primary importance among social-economic problems for $32.2 \%$ of respondents. $20.7 \%$ of respondents mentioned low income as the second major concern. Thus, over half of respondents are concerned over these two problems. During the interviews, the respondents also mentioned a problem of expensive airfares. The third most important issue is that local people are concerned over the lack of employment opportunities (18\%) and access to health care $(11,5 \%)$.

The respondents are rather serious about the assessment of environmental situation (Table 2).

Traditional nature management, such as reduction in deer population and change in their migration routes $(23,1 \%)$ as well as reduction in numbers of facilities of traditional industries (19,1\%) are issues of major concern of the local population. Respondents are also concerned over the lack of waste management and recycling system $(17,1 \%)$ and pollution of environment $(16,4 \%)$. Additionally, respondents from the rural localities of YuryungKhaya and Saskylakh of Anabarsky District, Yakutia, mentioned fall in water level in the Anabar River (12,3\% of respondents) which they associate with climate change, bank caving and mining companies' activity. In certain districts, namely the rural localities of Sred-

Table 1. Social-economic problems of concern identified by residents of Olenyoksky District, Yakutia

\begin{tabular}{|l|c|}
\hline \multicolumn{1}{|c|}{ Problem } & Ratio of total number of respondents (\%) \\
\hline Lack of employment opportunities & 18.0 \\
\hline Low income & 20.7 \\
\hline Increase in food prices & 32.2 \\
\hline Low level of health care & 11.5 \\
\hline Transportation problems & 17.6 \\
\hline Total & 100.0 \\
\hline
\end{tabular}

Table 2. Environmental issues that are the matters of concern for local residents

\begin{tabular}{|l|c|}
\hline \multicolumn{1}{|c|}{ Environmental problems } & Ratio of total number of respondents (\%) \\
\hline Environmental pollution (river, tundra) & 16,4 \\
\hline $\begin{array}{l}\text { Reduction in deer population and change in their } \\
\text { migration routes }\end{array}$ & 23,1 \\
\hline Reduction in numbers of facilities of traditional industries & 19,1 \\
\hline Lack of waste management and recycling system & 17,1 \\
\hline Poaching & 10,4 \\
\hline Climate change & 14,0 \\
\hline Total & 100,0 \\
\hline
\end{tabular}


nekolymsk and Svatay of Srednekolymsky District (Yakutia), the respondents also identified a problem of area flooding and overflowing in terms of thawing permafrost.

According to respondents (ratio of total number,\%), the issues related to traditional culture preservation in the territory of planned activity are as follows: the outflow of young people from the native area $(20,6 \%)$, lack of organized leisure $(18,9 \%)$, loss of ties with the native culture or traditions $(16,6 \%)$, a problem of sales of products of traditional industries $(17,6 \%)$, and preservation of the native tongue and culture $(26,4 \%)$.

In addition, the respondents emphasized the key areas where the mining company might provide assistance in resolving social problems, namely, housing construction (27,9\%), support of development of traditional industries $(21,1 \%)$, youth employment $(18,7 \%)$, development of transport infrastructure $(14,1 \%)$ development of social infrastructure $(12,6 \%)$, small business support (3,5\%), and development of tourism $(2,1 \%)$. Nearly half of the respondents are aware of the fact that the project for industrial development of the Arctic affords employment opportunities at home and contribute to improvement of the quality of life in the place of residence.

Sociological surveys carried out in the framework of ethnological evaluation of consequences of diesel fuel spill in Norilsk allowed establishing pressing social issues caused by environmental disaster. Alongside with the Internet survey, face-to-face interviews involving respondents representing all stakeholders including Nornickel employees were conducted as well. The survey was carried out in the period from August through October, 2020. It involved 170 residents of Taymyrsky DolganoNenetsky Municipal District, the Krasnoyarsk Krai, including $49,4 \%$ of men and $50,6 \%$ of women.

The respondents emphasized specific issues and changes that took place in their life activities after diesel fuel spill. For instance, they mentioned reduction in fish and meat in the district, increase in food prices, giving up traditional industries in the polluted areas, etc. The respondents also indicated the following challenges that local people faced after the accident (ratio of total number,\%), namely, harmfulness of fishing in the polluted areas $(22,8 \%)$, change in deer migration routes caused by petroleum products spill $(19,5 \%)$, fear for the health of relatives $(18,4 \%)$, changes in transportation activities $(4,3 \%)$, deterioration in the quality of life (22\%), and need for removal to a different district (13\%).

The respondents also gave the following comments on the problems emerged after the accident, "Representative of the indigenous peoples lost their income due to pollution», «the accident consequences caused reduction in income among the indigenous communities», and «it is difficult to provide for the families.» In addition, the respondents mentioned the changes in psychological condition after petroleum products spill such as fear, anxiety and deterioration of psychological situation among those living in the polluted territories (stress and depression). As for environmental changes and challenges, the respondents indicated impairment of quality of water that local people use for drinking. Meanwhile, a large percentage of respondents stated their willingness to cooperate with the mining company in terms of managing of accident consequences and addressing the emerging problems ( $74 \%$ ).

\section{Conclusion}

As a result of conducted surveys, a range of areas of social problems of the Arctic districts in the region of industrial development of the territory are identified, such as socialeconomic problems including low income and infrastructure development of the settlement area, ecological problems caused by environmental pollution, particularly in terms of the projects on industrial development of the Arctic region, and social-cultural problems determined by the difficulties of preservation of ethnic cultural traditions and types of traditional nature management. The problems identified are inextricably intertwined with each other as environmental degradation makes an impact on reduction in deer population and change in their migration routes, and low income is related to the lack of employment opportunities. The performed analysis shows that social 
problems identified in the area of industrial development of the Arctic districts are similar to those experienced by people elsewhere. However, a growing trend to identification of pressing social and cultural issues in terms of lost ties with the native culture experienced by people should be emphasized. In this regard, correlation between the outflow of people and cultural changes in the life of the indigenous peoples is observed. Comprehension of this problem changes the local people's understanding of traditional life in the Arctic regions.

Negative experience of industrial development in the Arctic also reinforces social tension. Alongside with the above mentioned problems, there is a lack of public awareness which sparks rumours, creates uncertainty, and causes fear among the local population.

Identified social problems should be taken into account in the framework of the projects of industrial development of the territory. Conducting social monitoring of local people's at- titudes towards the ongoing projects, high level of local people's awareness of the ongoing projects as well as paternalistic culture of mining and investment companies may contribute to reduction of social tension and rise in the standard of living of the indigenous peoples.

The approach suggested for public opinion study in the framework of justification of the projects on industrial development of the Arctic based on sociological surveys is aimed at developing a mechanism of social monitoring of considering the interests and needs of local population and addressing emerging social problems. Carrying out sociological surveys of the indigenous peoples of the North may contribute to designing programs on social and economic development of the territory (Novoselov et al., 2020), introducing procedures of taking into account the peoples' interests as well as developing new communication strategies of cooperation between the mining companies and the local residents.

\section{References}

Belonozhko, M.L., Silin, A.N., Barbakov, O.M., Gyurdzhinyan, A.S. (2018). Sotsial'nye problemy v samootsenkakh naseleniia arkticheskoi zony Rossii [Social problems in the self-assessment of the population of the Arctic zone of Russia]. In Sotsiologicheskie issledovaniia [Sociological Research], 4, 112-117. Available at: 10.7868/S0132162518040128.

Berman, M., Schmidt, J.I. (2019). Economic effects of climate change in Alaska. In Weather, Climate, and Society, 11, 245-258.

Burtseva, E.I., Potravny, I.M., Gassiy, V.V., etc. (2019). Ekonomika traditsionnogo prirodopol'zovaniia: vzaimodeistvie korennykh narodov Severa i biznesa $v$ rossiiskoi Arktike [The Economy of Traditional Nature Management: Interaction between the Indigenous Peoples of the North and Business in the Russian Arctic], Edit. by E. I. Burtseva and I. M. Potravny. Moscow, Ekonomika, 318 p.

Burtseva, E., Bysyina, A. (2019). Damage Compensation for Indigenous Peoples in the Conditions of Industrial Development of Territories on the Example of the Arctic Zone of the Sakha Republic. In Resources, $8(14)$.

Gassiy, V., Potravny, I. (2019). The Compensation for Losses to Indigenous Peoples Due to the Arctic Industrial Development in Benefit Sharing Paradigm. In Resources, 8(2), 71. Available at: https://www. mdpi.com/2079-9276/8/2/71

Denisov, V.N. Chernogradskii, I.M., Potravny, I.M., Ivanova, P. Yu. (2020). Directions of the Balanced Socioeconomic Development of the Arctic Zone of Russia (with the Example of Yakutia). In Studies on Russian Economic Development, 31(4), 404-410. Available at: https://ideas.repec.org/a/spr/sorede/v31y2020i4d10.1134 s107570072004005x.html

Gerth, H.H., Turner, B.S. (2009). From Max Weber: Essays in Sociology. London, Routledge, $490 \mathrm{p}$.

Novoselov, A., Potravny, I., Novoselova, I., Gassiy, V. (2020). Sustainable Development of the Arctic Indigenous Communities: The Approach to Projects Optimization of Mining Company. In Sustainability, 12(19), 7963. Available at: https://www.mdpi.com/2071-1050/12/19/7963 
Petrov, A.N., Tysiachniouk, M.S. (2019). Benefit Sharing in the Arctic: A Systematic View. In $R e$ sources, 8, 155. Available at: https:/www.mdpi.com/2079-9276/8/3/155

Potravnaya, E., Hye-Jin, Kim (2020). Economic Behaviour of the Indigenous Peoples in the Context of the Industrial Development of the Russian Arctic: A Gender-Sensitive Approach. In REGION: Regional Studies of Russia, Eastern Europe, and Central Asia, 9(2), 101-126.

Potravnaya, E.V. (2020). Gendernye osobennosti vospriiatiia ekologicheskikh problem korennymi narodami Severa Rossii [Gender features of perception of ecological problems by indigenous peoples of the North of Russia]. In Narodonaselenie [Population], 23(20), 73-85. Available at: 10.19181/population.2020.23.2.7.

Potravny, I.M. (2020). Etnologicheskaia ekspertiza posledstvii avariinogo zagriazneniia okruzhaiushchei sredy [Ethnological examination of the consequences of accidental environmental pollution]. In Ekologiia, Ekonomika, Informatika. Seriia: Sistemnyi analiz i modelirovanie ekonomicheskikh i ekologicheskikh sistem [Ecology. Economy. Computer science. Series: System analysis and modelling of economic and environmental systems], 1(5), 282-286. Available at: https://www.elibrary.ru/item.asp?id=44111583

Sleptsov, A., Petrova, A. (2019). Ethnological Expertise in Yakutia: The Local Experience of Assessing the Impact of Industrial Activities on the Northern Indigenous Peoples. In Resources, 8(123). Available at: https:/www.mdpi.com/2079-9276/8/3/123 (accessed: 07 May 2021)

Sleptsov, A.N., Potravnaya, E.V. (2020). Vliianie pandemii koronavirusa na zhizn' Arkticheskih regionov $\mathrm{v}$ otsenkah naseleniia [The impact of the coronavirus pandemic on the life of the Arctic regions in population estimates]. In Sotsiologicheskie issledovaniia [Sociological Research], 7, 144-147. Available at: https://www.isras.ru/index.php?page $\mathrm{id}=2623 \& \mathrm{jn}=$ socis \&j=85\&y=2020\&n=7\&base $=$

Kim, S.H. (2007). Max Weber. In Stanford Encyclopaedia of Philosophy (Cambridge University Press), 214 p.

Samsonova, I.V., Potravny, I.M., Pavlova, M.B., Semyonova, L.A. (2021). Otsenka ubytkov, prichinennykh korennym malochislennym narodam Severa v Taimyrskom Dolgano-Nenetskom raione Krasnoiarskogo kraia vsledstvie razliva dizel'nogo topliva na TETS-3 v Noril'ske [Assessment of losses caused to the indigenous peoples of the North in the Taimyr Dolgano-Nenets District of the Krasnoyarsk Territory due to the diesel spill at TPP-3 in Norilsk]. In Arktika: ekologiia i ekonomika [Arctic: Ecology and Economy], 11(2), 254-265. Available at: http://arctica-ac.ru/article/532/

Tysiachniouk, M.S., Henry, L.A., Tulaeva, S.A., Horowitz, L.S. (2020). Who benefits? How interestconvergence shapes benefit-sharing and indigenous rights to sustainable livelihoods in Russia. In Sustainability, 12(21), 1-22, 9025 .

Tulaeva, S., Tysiachniouk, M., Henry, L., Horowitz, L. (2019) Globalizing extraction and Indigenous rights in the Russian Arctic: The enduring role of the state in natural resource governance. In Resources. Available at: https://www.mdpi.com/2079-9276/8/4/179

Zander, E.V., Pyzheva, Yu.I., Pyzhev, A.I. (2014). Mekhanizmy kompensatsii ushcherba, nanosimogo predpriiatiiami-nedropol'zovateliami korennym malochislennym narodam [Mechanisms of compensation of the damage caused by the enterprises-subsurface users to indigenous small-numbered peoples]. In $R e$ gional'naia ekonomika: teoriia i praktika [Regional Economy. Theory and Practice], 7, 29-36.

Zarubina, Yu.N., Serova, E.A. (2018). Sotsial'nye problemy sovremennogo obshchestva [Social problems of modern society]. Yaroslavl, Yaroslavskii gosudarstvennyi universitet, $36 \mathrm{p}$. 